\title{
Lessons from Zhu Xi's Views on Inquiry and Learning for Contemporary Advanced Humanities Education and Research
}

\author{
Kirill Olle THOMPSON*
}

We don't read poetry because it's cute. We read and write poetry because we are members of the human race. And the human race is filled with passion. So medicine, law, business, engineering... these are noble pursuits and necessary to sustain life. But poetry, beauty, romance, love... These are what we stay alive for. (Kleinbaum 1989)

Whenever we proceed from the known into the unknown, we may hope to understand but we may have to learn at the same time a new way of understanding. (Werner Heisenberg)

\begin{abstract}
We are bearing witness to the rapid rise of a brave new world of education as flashy websites and interactive software replace individual study and classroom lectures. The expansion of college lecture halls has been stretched thin with video lessons and distance learning, and the siren call of massive open online courses (MOOCs) by star Ivy League professors renders the traditional classroom barren in the eyes of savvy students who have the system pegged.
\end{abstract}

Several questions arise in this context. Can the students of today receive a college education in the full sense? Does learning still have the same quality without close interactions with teachers and classmates in small to medium sized classrooms? Does research hold the same significance today when much of the work is done and so much information supplied by computers? What lessons do Zhu Xi's teachings on inquiry and learning have for this educational world of e-texts and cyber-lessons? While not a Luddite tract, the present study raises questions and concerns about the goals and conduct of higher education today which, as Heisenberg avers, should not only aim at transmitting knowledge understood in set ways, but also at inculcating new ways of thinking and understanding.

A college education, as Zhu Xi holds for "advanced learning", is as much about cultivating a thoughtful, responsible person as producing a professional expert. Such education should include cultivating a student's sensitivity, logic, and judgment, as well as knowledge

Kirill Olle THOMPSON, National Taiwan University,

Taipei, Taiwan.

ktviking[at]ntu.edu.tw

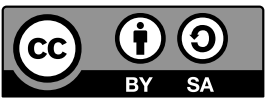


about humanity, society, and the world. It is often forgotten that such sensitivity, logic, knowledge, and commitment not only make the student more thoughtful and responsible, in short more self-conscious, but also give her additional perspectives and enhance her professional expertise.

Keywords: Zhu Xi, the humanities, advanced research, self-consciousness, moral perspective

\section{Predavanje $z$ Zhu Xijevega vidika o povpraševanju in učenju za sodobno na- predno humanistično učenje in raziskovanje}

\section{Izvleček}

V sodobnem svetu smo priča eksplozivnemu naraščanju izobraževalnih sistemov krasnega novega sveta. Bleščeče spletne strani in interaktivni programi so v nekaterih primerih že nadomestili individualne pedagoške pristope ter učenje $\mathrm{v}$ predavalnicah in učilnicah. Tako študij vse pogosteje poteka preko posnetih predavanj in učenja na daljavo. Skušnjave množičnih spletnih tečajev odprtega tipa so že premamile marsikaterega študenta in marsikdo že meni, da so tradicionalne učilnice zastarele in premalo učinkovite.

$S$ tem se odpira vrsta vprašanj. Ali imajo študentje na sodobnih fakultetah sploh še možnost pridobivanja celovite univerzitetne izobrazbe? Ali je pouk brez osebnega stika med učitelji in učenci v fizičnih učilnicah res enako kakovosten? Ali je raziskovanje dandanes, ko lahko veliko dela namesto nas opravijo računalniki, ki nas zalagajo z nepregledno množico informacij, še vedno enako pomembno, kot je bilo prej? In kaj bi nas lahko v svetu digitalnih besedil in spletnih tečajev naučil Zhu Xi? Študija sicer nima namena najti rešitve za vse probleme, ki nastajajo v procesu omenjene tranzicije, vendar obravnava vprašanja, povezana s cilji in postopki sodobnega izobraževanja, ki naj bi, kot poudarja Henderson, pomenilo več kot zgolj posredovanje znanja. Pravo izobraževanje bi moralo namreč temeljiti tudi na uvajanju novih načinov razmišljanja in razumevanja.

Zhu Xijevo tako imenovano "napredno učenje«, ki je primerljivo s sodobnim univerzitetnim izobraževanjem, se ne osredotoča zgolj na proizvodnjo strokovno podkovanih specialistov, temveč tudi na kultivacijo razmišljajočega, odgovornega človeka. Takšna izobrazba mora vključevati tako razvoj logičnega mišljenja in razumnega odločanja kot tudi razumevanje človeka, družbe in sveta. Dandanes se pogosto pozablja, da je treba faktično znanje in logično razmišljanje povezati tudi s senzibilnostjo in predanostjo; takšna celovita izobrazba pomaga študentom do večjega samozaupanja, hkrati pa odpira nove perspektive in s tem izboljšuje tudi njihovo strokovno znanje.

Ključne besede: Zhu Xi, humanistika, napredno raziskovanje, samozaupanje, moralne perspektive

\section{Introduction}

We contemporary scholars feel empowered by our access to digitized data and research materials, not to mention the research aids, search engines, and data 
crunchers at our fingertips. We enjoy unprecedented data reach and computational capacity, as well as tools for compiling and arranging materials for our research work and writing. Indeed, I can only imagine the sorts of digital research paper templates now available, and wonder what would $\mathrm{Zhu} \mathrm{Xi}$ make of these rich data troves and analytic tools? How would he assess the computer assisted approaches people now take in conducting research, reflection, and writing, in the humanities in particular? ${ }^{1}$ Would he regard it as adaptable to one's larger purpose of dedicated self-cultivation and person-making, or as inimical to this? ${ }^{2}$

One might respond that Zhu Xi's notion of inquiry and learning is closely bound up with his concept of self-realization under a specific set of values and cultural practices, at some remove from the free-spirited, liberal sort of education that typifies this day and age. For the present discussion, however, let us grant that Zhu Xi's value orientation and notion of knowledge and learning are sufficiently general to be relevant for assessing the advanced level approaches to research, reflection, and writing that are now adopted, and especially in the humanities.

Believing that nature and human life operate according to given sets of patterns, formations, and principles, which make them essentially understandable, ${ }^{3}$ Zhu $\mathrm{Xi}$ would tend to consider that "humanities" research, reflection, and writing in general should elicit similar sets of patterns and formations, and provoke, whether implicitly or explicitly, similar patterns of cultivational, humanizing self-reflection, development, and realization. That is, while $\mathrm{Zhu} \mathrm{Xi}$ does adhere to a specific set of Confucian values, cultural practices, and cultivation goals, we here make the assumption that he would tend to see similar sets of values, practices, and goals in play in almost any sincerely and openly conducted humanities reflection, research, and writing. I would venture to add that university and advanced level humanities research and writing in today's universities are thought to involve a project of self-cultivation, reflection, and realization as the student/researcher ipso

1 I highlight humanities research, reflection, and writing in particular because they are construed to have, to a certain extent, a cultivational, humanizing effect on the researcher/writer (Nussbaum 1998). Research, reflection, and writing in other fields should have this effect, as well, in terms of the logic and values involved in conducting research, reflection, and writing with honest objectivity, yet with a sense of compassion and good purpose. Humanities research, reflection, and writing tend to involve additional personal self-examination and value reflections.

2 In the Southern Song, Zhu Xi was already concerned that the easy availability of mass printed books was detrimental to learning and cultivation, for students increasingly no longer needed to memorize and recite texts or take them so deeply to heart. He also feared the proliferation of commentaries that could be misleading as often as they were enlightening.

3 Zhu Xi understood these patterns and formations as mapped into focus-fields, li- $q$ i (理氣) orders and aesthetic order, and as manifested variously and to be discerned in diverse lights and perspectives. On focus-field and aesthetic order, see Hall and Ames 1987. On li-qi orders, see Thompson 2015, 150-6. 
facto breaks through her original naive, parochial, biased views and values along the way to establishing the epistemic objectivity, value awareness, and authority necessary for preparing her dissertation, launching her career, and becoming a fully responsible, self-conscious human being. ${ }^{4}$

\section{Cultural and Cultivational Context of Zhu Xi's Approach to Inquiry and Learning}

Zhu Xi's approach to inquiry and learning is bound up with what he regards as the core cultivation efforts of abiding in jing 敬 (reverence), nurturing the root, and examining the self. For the present considerations, we can regard jing as covering the attitudes of concentration, openness, and alertness. Mindfulness has been offered as a suggestive cover term for jing cultivation and practice. ${ }^{5}$ Nurturing the root is about preserving one's native moral propensities, sense of fairness, and impulse toward goodness and truth. ${ }^{6}$ It is to free oneself of acquired prejudices, biases and self-centeredness. ${ }^{7}$ Moreover, self-examination refers to assessing the probity of one's motivations and the sincerity of one's intentions, particularly in learning and inquiry in this case, but also in one's life conduct in general. Moreover, Zhu Xi also came to understand that, in order to have purpose and be fruitful, one's inquiry and learning need to have dedication and purpose, so he stressed establishing resolve (lizhi 立志) as crucial, and cast off his practice of offering learning packages or outlines:

...it is essential for learners to establish resolve. Consider the saying, "Strive to restore the roots of one's basic propensities (xing 性) and

$4 \quad$ Back in the 1970s, some professors of metaethics stressed that metaethical analysis was purely objective, and to be conducted irrespective of any particular set of normative rules. One professor of mine even gave the example of the ethicist McTaggart, a century earlier, shooting neighborhood cats in the night, arguing that the best metaethical analyst might have no personal ethical commitments. At the time, colleagues and graduate students countered that simply by virtue of being a responsible member of a family, community, etc., such an analyst would still recognize and follow basic normative rules that make civilized life possible. Virtually all humanities disciplines deliver insight into the importance of values and rules. The best metaethicist should thus know the importance of values and rules in her bones.

5 I use the Romanized Chinese term jing 敬 in the following, taking reverence or reverential regard as the core, and concentration, seriousness, and mindfulness as connotations that, respectively, gain relevance in context.

6 This harks back to Mencius' teachings on basic human propensities, the four beginnings (siduan 四 端), and inborn knowledge of the good (liangzhi 良知) (Lau 1970). These are basic planks in most liberal humanistic outlooks.

7 One thinks of Plato's dialogue Meno (Guthrie 1956), which shows how faulty knowledge can lead people astray. 
endowment (ming 命), ${ }^{8}$ aspire to surpass the achievements of the sages and worthies." One who establishes resolve will make determined efforts. It doesn't do to just aim to be a good person and rest content after realizing several daoli (道理; general truisms). ${ }^{9}$ Such a person won't make further progress. Consider, rather, Yan Hui's "inability to give up, even if he had wanted to" (Analects 9.11; Ames 1998, 128f), and the petty man's "working tirelessly for his own benefit", constantly bearing it in mind (Mencius 7A:25; Lau 1970,187). The cultivation effort of those who lack in resolve will not succeed in the long run. (Zhu 1986, ch. 118)

The resolve that drives one's conduct of inquiry and learning is existential, and will continue to empower one throughout life. Indeed,

In the conduct of all sorts of affairs, one must first establish resolve. One maintains jing in the midst of conducting affairs and things... One's resolve, however, transcends the matters at hand; thus, it can't be overwhelmed and shattered into tiny pieces. (ibid., ch.118)

Zhu even maintained that the achievements of Confucius, the sage, could be attributed, not just to his gifts, talents, and special destiny, but to the existential resolve of his deepest purpose.

In the world are countless roads and crossings, why didn't the sage take other roads? He only arrived at this particular juncture because his [existential] resolve expressed his deepest purpose. (ibid., ch. 23) $)^{10}$

At the same time, Zhu cautioned that one's resolve and dedication should not be translated into an exclusive concern with certain focal texts and topics. While pursuing core projects and concerns, the learner/researcher should stay open, alert, observant, and develop a practical grasp of the things around her, so as to add texture and depth to her knowledge, and thus enhance her versatility in responding

8 This carries the connotation of one's life mission, particularly in terms of interpersonal responsibilities to family, society, and career.

9 Zhu $\mathrm{Xi}$ is contrasting empty, wooden truisms with the deeper array of organizing patterns that constitute life and value, and motivate cultivation. Zhu Xi's use of daoli here diverges from modern Mandarin, in which questioning whether an idea or proposition has any daoli is to asking whether it is reasonable, that is to say, reasonably grounded.

10 Much is made of Confucius' nurturing a hoary tradition, but he learned from many teachers and his greatness lay in continuously reorienting tradition on an ethical foundation of mutual care and responsibility. His example proves Sartre's observation, "There is no traced out path to salvation; one must constantly invent one's own path. But, to invent it, one is free, responsible, without excuse, and every hope lies within him" (Flynn 2014). 
to all matters. Such a grasp and versatility distinguish a vital learner from an empty pedant, and make one's life increasingly resonant and fluent.

Generally, in free time one should strive to grasp the things at hand. By developing a practical grasp of things, whenever you encounter new affairs your knowledge will be extended case by case. But, people nowadays feel disinclined to grasp things in their leisure time. When they encounter affairs they balk at investigating their daoli ${ }^{11}$ anew and take ease in their own shallowness and vulgarity. Such people don't mature or make much progress; in the end, they have no achievements. The problem is that they lack resolve and waste their lives in vain. (Zhu 1986, 15)

Moreover, establishing resolve does not involve casting off guided programs of learning per se. Rather, it empowers one to get more out of such systematic learning while not becoming narrow and enclosed within it as an epistemic cocoon.

Having established resolve, one should still endeavor to learn gradually step-by-step, bearing the general framework of appropriateness and pattern $(y i l i \text { 義理 })^{12}$ in mind. Thus determined, one who feels trepidation can engage in discussion, nurture the root, practice self-examination, and expect to make some progress. Those who are satisfied to be dabblers need to wake up and redouble their seriousness, jing, dedication, and nurturing, lest their progress be intermittent and their efforts wasted for lacking the certitude of clear comprehension and the efficacy of personal experience. (Zhu 2002, ch. 55, letter to Chen Zhaozeng)

Zhu Xi's primary cultivations of abiding in jing, nurturing the root, examining the self, and establishing resolve are attitudinal, orientational, and existential. They keep one grounded and centred as one embarks on inquiry and learning, and facilitate one's efforts at knowledge acquisition, self-transformation, and self-realization. When $\mathrm{Zhu} \mathrm{Xi}$ speaks of staying open to the things going on, it reminds us of the long-term value of acquainting oneself with a variety of fields to establish a well-rounded knowledge of humanity, society, and nature, and have a context for appreciating one's own chosen field. ${ }^{13}$

11 In this passage, daoli pertains to the operative general patterns that shape and guide phenomena and events. The meaning thus differs from its alternative usage discussed in note 9 , above.

12 Appropriateness ( $y i$ 義) pertains to one's sensitivity and discernment as to what is most fitting in context, all things considered, against the backdrop of immanent patterning ( $l i$ 理), that structure and balance phenomena and events.

13 James Austin underscores the positive role of side interests and knowledge in enhancing one's ability to see connections and creativity (Austin 2003). As Austin shows, Alexander Fleming's side interests, extracurricular knowledge, and quirks were indispensable to his discovery of penicillin. 
Even in this brave new world of computerized learning and research and digitized data, advanced students and researchers understand the need to stay committed and motivated to achieve their educational goals. They have demonstrably less cognizance, however, of the need to abide in jing, nurture the root, and examine the self. That is, they lose sense of the need to stay alert and be aware of everything one does, to maintain one's basic sense of innocence and humanity, and to reflect on what one is thinking and doing. Computerized learning and digitized data are highly mediated and automated, and stir a sort of distancing from the self and mindlessness that can lead to self as well as other alienation. Moreover, the more one keeps directly interacting with digital machines through keyboards and monitors, the more one's crucial interpersonal intercourse becomes indirect and mediated. In this sort of increasingly impersonal cognitive environment, any notion of nurturing the root would tend to go by the wayside, and self-examination would have more to do with data management skills and control than with examining the probity of one's ethical conduct and conscience. ${ }^{14}$ Yet, without doubt, such attitudinal, orientational, and existential cultivations remain necessary to the proper and personally enriching conduct of advanced reading, reflection, and research in the humanities.

\section{Conducting Inquiry to Attain Knowledge}

The notion of "attaining knowledge" (zhizhi 致知 $)^{15}$ is central to Zhu Xi's approach to cultivating mind, and he insists that one attains knowledge by actively investigating things. For Zhu, attaining knowledge is tantamount to exploring their constituent patterns and propensities. Zhu's account of knowledge seeks a sort of working "knowing that", getting things right, the value of which lay in the Rylean facet of "knowing how". That is, the getting things right is in order to inform one's responses. Since so much Confucian knowledge has to do with propriety and appropriateness in conduct, the accumulation of such knowledge,

14 This does not necessarily mark an East-West difference in approaching humanities research. I would instead put it that traditional, pre-computerized humanities research in the West tacitly involved the assumption of Zhu Xi's attitudinal, orientational, and existential cultivations. By the same token, contemporary students of $\mathrm{Zhu} \mathrm{Xi}$ will use computers and digital data to access his writings and his ideas. Whereas traditional students had to plod and ponder his texts, turning to printed dictionaries along the way, the new breed roams enhanced texts with built-in dictionaries and explanations that appear at the press of a key. However, with the exponentially expanding use of study aids of all sorts, too many standard answers are given and facile understandings arrived at. The reduced pondering, too, results in less intimacy and resonance with the text, as one's own tacit assumptions and lines of approach remain unchallenged as one heedlessly plows ahead.

The connotation of "extending knowledge" is often implied. 
be it knowing how or knowing that, ${ }^{16}$ lays the ground for attaining performative "tacit knowledge", a la Michael Polanyi (1966, 2002). Zhu remains concerned with accuracy and getting it right; for not only do we depend on such proper understanding to inform our instincts and emotions, and guide our judgments and actions, many moralists make mistaken judgments and make inappropriate responses precisely because they do not know the warp and woof of the world in depth, but only general truisms and customs of the tradition. ${ }^{17}$

What then does Zhu mean by "investigating things"? He generally supports Cheng Yi's account of "investigating things", which involves striking a balance between subjectivity and objectivity, perspective and detail. $\mathrm{Zhu} \mathrm{Xi}$ is attentive to striking this sort of balance in his own approach to investigating things to attain knowledge. By developing the notion of pattern as the nexus of order and knowledge, and stressing a commonality of pattern, patterning in the heart-mind and in phenomena and affairs, Zhu epistemically seeks a sort of inner resonance in investigating phenomena and affairs. Achieving such an inner resonance is important, since patterns are implicated not just formally and cognitively, but also emotively and interactively, in their instantiations (basic propensities) and settings. The knowledge one attains involves grasping such patterns and propensities in the contexts, or matrices, of their interactive relations, as well as one's impulses of appropriate response.

To be sure, Zhu Xi broadened Cheng Yi's account of investigating things and made it more inclusive. In this effort, he gave the first definitive Neo-Confucian account of investigating things in the "Supplement on investigating things" he appended to chapter 5 in the Advanced Learning (大學 Daxue), which reads:

The expression "attaining knowledge lies in investigating things" means that, if one intends to attain knowledge, it lies in exploring the patterns of the things one encounters. Indeed, there is nothing the discerning human mind cannot comprehend, for there is nothing in the world that doesn't possess patterns. It is just because there remain some patterns one hasn't explored that one's knowledge is not exhaustive. This is why the first step in advanced learning is, regarding everything in the world, for

16 Gilbert Ryle's famous distinction between knowing that and knowing how (Ryle 1949). Knowing that is cognitive and discursive and involves confirming the facts. Knowing how is behavioral and often cannot be put into words. I would put that for Zhu Xi a continuum exists between the knowing obtained by study and knowing how, in that all sorts of "knowing that" inform one's considerations, judgments, even impulses, in taking action. He would agree with biologists that every bit of knowledge feeds into our epistemic maps for navigating and responding to events as best we can; for Zhu Xi, it would be "as appropriately we can, and with utmost propriety".

17 The Buddha was similarly concerned with accurate knowledge to support enlightened awareness and conduct. 
the learner to proceed in each instance on the basis of what he already knows of their patterns, to explore them further in order to understand them to the utmost. Having exerted oneself at this for a long time, one will suddenly have a penetrating comprehension. One will penetrate the latent and the manifest, the seed and chaff of all things and understand the whole substance and far-reaching function of mind. This is what is called "investigating things", it is what is called, "the utmost of knowledge" (adapted from Chan 1963, 89).

Notably, since the self-same patterns/patterning constitute the heart-mind as form the living world, the investigation of things and affairs discloses not only their patterns of formation and intercourse but ipso facto the patterns constituting the heart-mind and its perceptual and responsive operations. For Zhu Xi, object realization as much as other realization is a mirror to reflexive self-realization. At the same time, how can one hope to comprehend "all things in the world", even in principle? Zhu Xi explains that patterns/patterning are patterned, comprehended, and manifested throughout reality. Since the patterns unfold organically in the flux of phenomena and the formation and development of things, they are all organically related, parallel, symmetrical in form, and can be traced back to their originating form as the single pattern. ${ }^{18}$ Hence, every new bit of knowledge one acquires, every new facet of pattern one grasps, casts additional light onto the new phenomena and the constituent patterns that one encounters.

These subtle, fine-mesh daoli are utterly inexhaustible. There is no dimension in which they aren't manifested. They penetrate and connect all the myriad complexities (Zhu 1986, ch. 22).

The manifold complexities ultimately all trace back to the one pattern (ibid., ch. 41).

Daoli is distributed amongst all things and affairs. It definitely isn't concentrated in one place (ibid., ch.120).

Such daoli penetrate everywhere equally-seed and chaff, small and large-in every direction. Grasp all four sides together in comprehending them (ibid., ch. 116).

For Zhu, this extension, unfolding, and dispersal, not to mention folding and return, of patterns throughout the world mean that patterns are at once integrated and also manifested variously in multi-perspectival ways. For this reason, one

18 The originative single pattern would be supreme polarity (taiji 太極), which triggers the yin-yang polarity in $q i$. 
has to be constantly prepared to adjust one's pre-conceptions and stance to see through the phenomena appropriately, and grasp their patterns effectively. Zhu observed this need for multiple perspectives for understanding human affairs, natural phenomena, and even artefacts. ${ }^{19}$

The learning of the common person usually deviates toward one set pattern and stresses one position. Therefore, fierce debates break out because people don't see all four sides. ${ }^{20}$ The sage [Confucius] stayed balanced, upright, in harmony and fair, and thus remained free of deviation or bias. $(\text { Zhu 1986, ch. 8) })^{21}$

Although the myriad patterns are ultimately expressions of the single [originative] pattern, learners still must attend to the manifold complexities within the myriad patterns. By drawing together all four sides, they will naturally realize the single pattern. Not attending to those myriad patterns but attending solely to one set pattern is groundless imagining. (ibid., ch.117)

Gather examples of all species in order to observe the spirit of transformations in nature. Collect all kinds of construction materials to understand their respective functions in the building of a house. One must release one's mind and spirit in order to pay attention. (Zhu 1986, ch. 117)

What is important is to comprehend inner and outer, root and branch, hidden and manifest, seed and chaff, completely and comprehensively in each respect. (ibid., ch.18)

Interestingly, in Zhu Xi's account of patterns/patterning in the "Supplement to Chapter 5" quoted above, he elaborates on patterns/patterning in more or less general and specific, abstract and concrete senses. ${ }^{22} \mathrm{Zhu} \mathrm{Xi}$ also stresses time and again that "understanding [a] pattern exhaustively" must be undertaken on the basis of investigating things; he sees no sense in examining the idea of pattern simpliciter, in abstraction from phenomena; for the significance of patterns/patterning surely lies in its formative role in processes, cycles, phenomena, and affairs. $\mathrm{Li}$ must be implicated in phenomena or affairs to be discernible and have epistemic value, practical traction, and ethical significance.

19 See Zhuangzi's similar position in ch.17, "Autumn Floods"(Watson 1968), and also see Thompson (2015, 150-6).

20 "Four" stands for multiple.

21 A reference perhaps to Confucius' four abstentions (Analects 9.4; Ames 1998, 127).

22 This can perhaps be likened to Russell's notion of type levels and Hegel's notion of levels of abstract universals and concrete universals 
Is any of this instructive for the contemporary computer-assisted conduct of research, reflection, and writing? I would tend to say yes. While we might not subscribe specifically to Zhu Xi's ontology of pattern, or pattern and qi, his underlying conception of patterns/patterning, set in real dynamic contexts, remains instructive and provides a handle for understanding and responding to things and affairs. ${ }^{23}$ The notion of pattern cuts to the chase of human perception and knowledge, as contemporary neural science tells us that our perceptions are coded on the basis of pattern recognition, which apparently goes much deeper and is more exacting than, say, the venerable Aristotelian categories. ${ }^{24}$ I would add that whenever we conduct research and reflection, we arrange sets of relevant distinctions and categories for the data for the purpose of that project. We could say that the logic, categories, and structure that we project in our understanding of the data tend to shape both the data sets (the phenomena) we are dealing with and our mindset as we attempt to conceptualize the data and work with them. In that sense, the selfsame patterns are at work together both in (our views of) things and affairs and in our minds and conceptualizations, particularly as our understandings get closer to the truth. So, it is important not only to get things right, but also to think about the things in a relevant and effective, systematic order.

Importantly, $\mathrm{Zhu} \mathrm{Xi}$ at the same time understands that we can and do get things wrong and invariably need to rethink everything when the data, or experiential or experimental results, turn out very differently from our conceptual or hypothetical expectations. Zhu $\mathrm{Xi}$ understands the provisional nature of human understandings of the structure and processes of the world; hence, he knows that an accurate account of a pattern with respect to knowledge and, by extension, value, would refer it to the final outcome of ongoing inquiry and reflection, rather than something given as understood at the outset..$^{25}$ It is important to realize that Zhu Xi's notion of the this same patterns/patterning permeating world and mind is reminiscent of the early Wittgenstein's claim of a common logical space answering to world, language, and thought, by virtue of which language - and knowledge - mirrors reality and allows us to talk about real facts. Zhu's notion of the basic intelligibility of the world by virtue of the patterns which permeate and run through it parallels Wittgenstein's idea that every state of affairs in the world, in principle, can be expressed as a fact in

23 See David Wade, Li: Dynamic Form in Nature (2003).

24 Think of the thousands of faces we can distinguish based on raw pattern recognition as compared to the relatively few we could distinguish using Aristotelian categories. Neural research shows our categorical understanding is parasitic on our pattern recognition, without which it could not take place. See Hawkins 2004, 60f.

25 This result is consistent with the "Supplement to Chapter 5" of the Great Learning and exemplified in some of Zhu Xi's observations of natural phenomena. 
language, and so that my language constitutes my world. Zhu Xi would be committed to the notion that we express our cognizance of patterns/patterning propositionally, and manifest that understanding performatively through speech and action. ${ }^{26}$

\section{Responsive Chord within Cognition}

A decisive plank in Zhu's "Supplement to Chapter 5" of the Advanced Learning is, "On the basis of what one already knows of their patterns, to explore them further". This key insight harks back to the notion of instinctual human responses, ${ }^{27}$ as well as knowing how and the tacit knowledge one builds up of how things happen in the world. ${ }^{28}$ Though this might seem to be a departure from foundational, "objective" Western styled research, in the humanities one tends to conduct research on topics that one feels an affinity with and responds to, that strike a chord, that resonate. I would propose that the researcher's resonance with his or her chosen research area contributes to his or her arriving at an approach and basic argument about the data. ${ }^{29}$ Furthermore, this notion of resonance helps to explain the underlying human reasonableness of giving charitable readings or interpretations. Such readings are not merely charity work conducted out of sympathy, but reflect that the critic's responsiveness to the author's basic feelings and take on the material. Uncharitable readings and interpretations are often false to the extent that they depart from the inclination and spirit of the original and push it in alien directions, which might be formally justified but are just false to the spirit of the material, even to the spirit of the argument. For example, many critical expositions of arguments in Plato are only correct when the arguments have been abstracted from their dialogical contexts and ironed out to fit logical stencils, however they miss subtleties and nuances of the dialogue and its context, and thus turn out to be irrelevant or merely a sidelight to Plato's own intentions and project. For his part, Zhu explains:

One must pay attention on the basis of one's instincts (Zhu 1986, ch. 8).

One must infer from what one knows in order to eventually reach the level of knowing all (ibid., ch. 15).

26 Thus answering to the later as well as early Wittgenstein.

27 This refers to preserving the root and Mencius' four beginnings, etc., mentioned above. See note 6.

28 See Zhuangzi's comments on the knowledge of nature and the knowledge of the human, and the knowledge that one knows vis-à-vis the knowledge one does not know in the opening paragraphs of Zhuangzi, chapter 6, "The Venerable Teacher" (Watson 1968). Wittgenstein offers similar reflections in On Certainty (Wittgenstein 1971).

29 This goes on as well in much research that is deemed prima facie objective. Even mathematicians and physicists speak of the beauty (aesthetics) of a compelling, well-formed argument or theory. 
What learners mean by “investigating things" nowadays lacks initial clues and is merely blindly investigating by inquiring into things (Zhu 1986, ch. 15).

To date, all verifiable knowledge is human knowledge, and to that extent subject to human sensitivity.

\section{Investigating Things to Extend Knowledge}

Zhu's "Supplement to Chapter 5" of the Advanced Learning enjoins us to, "Seek to reach its ultimate". This imperative involves making efforts to attain an understanding of the full range of the implications of a phenomenon, concept, or value. This is not pointing to an essentialist platonic ideal, but rather the full range, the full gamut of what a phenomenon, concept, or value involves. As Zhu Xi explains:

Everyone knows that a son knows to be filial, and a father knows to be affectionate. The problem is that people just don't understand these virtues thoroughly. What's important is to want to understand these virtues in depth. Consider a light shining through a hole. The light grows brighter when the hole is enlarged. All things have their patterns, and people are acquainted with their own [constitutive life] patterns, such as filiality and affection. But, if one's knowledge is not very penetrating it is as if one remains mostly in the dark. (ibid.)

Hence, Zhu's imperative "to reach its ultimate", is intended to encourage people to reach a penetrating comprehension of the concept or matter or value under consideration. If one's penetration is shallow one's comprehension will be weak and unsteady, like the narrow beams of light peeping through tiny holes. While students tend to be uninterested in thinking about basic issues like filiality and eager to consider more exotic, esoteric matters, Zhu Xi considered that people who remain unclear or in the dark about such basics as filiality and filial affection would tend to be fuzzy headed and unable to grasp the deeper things very well. Therefore, he set up genuine or authentic working knowledge as a goal,

"Attaining knowledge" is the means by which one seeks authentic knowledge.

Authentic knowledge involves penetrating things to the marrow to comprehend them thoroughly. (ibid.)

Knowledge, to be authentic, must penetrate to the marrow. Thus, the Master further said, "Investigating things is just attending to 
phenomena, while the knowledge attained is this mind's penetrating comprehension". (ibid.)

Cutting through the metaphors, we may consider Zhu Xi's notion of penetrating knowledge as in-depth knowledge that is at once detailed and comprehensive. For $\mathrm{Zhu} \mathrm{Xi}$, this would involve sensitivity to fine details, distinctions, and differences. He stressed the importance of achieving penetrating, in-depth knowledge, sensitive to fine distinctions, because he saw that many people judge things crudely and act on vague, general concepts, and thus while they might make judgments and perform actions that are prima facie in accord with custom and virtue, on a closer look they actually violate or contradict the values of propriety and humaneness. ${ }^{30}$ In the case of values, in particular, one arrives at a penetrating comprehension by drawing inferences in a variety of cases cued by one's basic impulses in response to what one intuits and knows within.

Consider King Xuan's seeing an ox and feeling that he couldn't bear the suffering of others [Mencius 1A:6]. To extend this feeling such that all things are covered by its empathetic concern is precisely what is meant by "investigating" and "attaining". This is to investigate, infer, explore, and attain to the utmost. Each person has his own store of knowledge and experience to draw on; nobody can be called completely ignoranteven the infant knows to love its parents and, as it grows up, to respect its elder brothers and so forth, down to knowing the basic distinctions between good and bad and right and wrong, which one then discerns clearly. But, as to one who doesn't go on to infer, extend, and expand on such feelings, experiences, and knowledge, one's experience and knowledge will, ultimately, remain like this. [...What is important is to explore and investigate on the basis of the clues of one's initial feelings]. (ibid.)

This passage goes beyond one's usual study and inquiry to consider the inborn moral sensitivities that begin to inform the researcher and develop in her thinking in the course of conducting humanities research. I stress moral sensitivities as opposed to strict virtues or principles, because this involves filling out and refining one's basic responsive life knowledge with the deeper lessons and insights that take place as one undertakes research and reflection in the humanities. We might say that $\mathrm{Zhu} \mathrm{Xi}$ stresses the importance of sensitivity and empathetic inquiry, and the bottom line is that one put oneself fully into it.

30 For this reason, Zhu Xi, following Mencius, spoke of the need to overturn ritual to fulfill humaneness in cases in which a standard observance of the ritual would cause harm or suffering. 
In investigating things, what is important is to pay close attention through the self. (Zhu 1986, ch.15; italics added)

To just explore the patterns of the myriad things in the world broadly, without endeavouring to grasp them through the self, is what is described by... [the Cheng Masters] as "galloping off with no point of return." (ibid., ch. 18; italics added)

Putting one's heart into it is clearly a departure from the disinterested objectivism that is encouraged by so-called advanced, computer-driven research in today's digital data. However, as $\mathrm{Zhu} \mathrm{Xi}$ would remind us, the very nature of humanities materials calls for sensitivity and empathetic reading and inquiry. The humanities researcher who does not read, reflect, and respond in a responsive, humane way will not be up to the task.

Putting one's heart into it turns out to be epistemologically justified for $\mathrm{Zhu} \mathrm{Xi}$, in that his notion of heart-mind is emotionally (and responsively) as well as cognitively (and rationally) wired into the living world of $q i$ and patterns/patterning such that,

...there is nothing the discerning human mind cannot comprehend, for there is nothing in the world that doesn't possess patterns. It is just because there remain some patterns one hasn't explored that one's knowledge is not exhaustive. This is why..., regarding everything in the world,... the learner proceeds in each instance on the basis of what he or she already knows of their patterns, to explore them further in order to understand them to the utmost. (Daxue zhangju, ch. 5)

Not only is putting one's heart into it epistemologically justified for Zhu Xi; since the same pattern/patterning constitute the heart-mind and knowledge as the world, phenomena, and affairs, one's exhaustive knowledge of the world is tantamount to exhaustive knowledge of the heart-mind and self, not to mention humanity.

Since the heart-mind is limitless, how could it be exhausted? Since things are countless, how could they be exhausted? But, one who reaches the level of penetrating realization and really grasps it will understand it all. This is to be exhaustive. (Zhu 1986, ch. 60)

One can't exhaust the function of heart-mind; what can be exhausted are just the patterns/patterning of the heart-mind. (ibid.)

Ultimately, we, "Investigate things in order to illuminate this very heartmind." (ibid., ch. 118) 
"Illuminate this mind" refers to the inner realization that one has arrived at penetrating knowledge, authentic knowledge, which gets into the marrow. This is the sort of knowledge one acquires by investigating things to explore patterns/ patterning. One who has explored the patterns of numerous phenomena, and reached the level of a sudden penetrating realization, in effect, has fully grasped the patterns/patterning of the heart-mind; thereafter, one is equipped to see through the myriads sorts of matters that arise. For $\mathrm{Zhu} \mathrm{Xi}$, one who is armed with this sort of penetrating realization is equipped to grasp quite readily any new things as they arise.

Nobody conducting inquiry and research in the humanities, or even the human sciences, would today make such sweeping claims for the general applicability of their epistemico-ontological assumptions, such as Zhu Xi's basic ideas of patterns/ patterning, $q i$, basic propensities, and heart-mind. However, these assumptions do not make Zhu's ideas or system rigid or limited. They stir the imagination, and provide useful ways to look at the facts and assess our feelings. One must keep in mind at the same time that Zhu Xi's ideas of patterns/patterning and daoli do not form a linear, logocentric system, but rather are multivalent, holistic, and regarded as organically unfolding as well as re-enfolding. As noted above, this extending and dispersal, as well as folding and return, of patterns/patterning throughout this flowing world mean that patterns/patterning are regarded as at once integrated and also manifested variously in multi-perspectival ways, such that one has to constantly adjust one's ideas and stance to grasp the phenomena and their basic propensities and guiding patterns sensitively and appropriately. Zhu Xi thus observed the need for multiple perspectives for understanding human affairs, natural phenomena, and even artefacts. ${ }^{31}$

Although the myriad patterns ultimately are expressions of the single [originative] pattern, learners still must attend to the manifold complexities within the myriad patterns. By drawing together all four sides, they will naturally realize the single [originative] pattern. Not attending to those myriad patterns but attending solely to the single originative pattern is groundless imagining. (Zhu 1986, ch. 117)

The learning of the common person usually deviates toward one set pattern and stresses one position. Therefore, fierce debates break out because people don't see all four sides. The sage [Confucius] stayed balanced, upright, in harmony and fair, and thus remained free of deviation or bias. (ibid., ch.8)

31 See Zhuangzi's similar position in ch. 17, "Autumn Floods" (Watson 1968). 
The argument might be made that Zhu Xi's system and approach allow for multiple perspectives and understandings, for multivalency and different reads of the basic propensities and patterns, because they are more about life praxis than theoretical understanding, which is the typical goal of advanced inquiry at present. They are not about reaching the sort of definitive explanation and understanding that are the earmarks of traditional Western philosophy and contemporary advanced research, in the humanities as in other fields. For the moment, I would propose that Zhu Xi's system and approach are aimed at precisely the sort of subjective comprehension (objectively validated, nonetheless) that lends itself to enhanced self-realization and self-conscious personhood and practice that remain the everlasting, though increasingly tacit, goal of work in the humanities, whether creative or academic.

\section{Zhu Xi on the Conduct of Learning and Reading}

Again, for Zhu Xi, learning and reading are part of one's self-cultivation efforts and goal, essentially to become a sensitive, responsible, and self-conscious person, dedicated to humane values and living. The value to be derived from mastering the subtleties of the texts lay in the basic truths of life they convey, their ethical import. Zhu Xi was critical of those students of ancient texts who seek esoterica and "enjoy mysteries and subtleties. They even probingly speak of the imageless and formless (which are unspeakable)." (ibid., ch. 26)

By contrast,

The sage (Confucius) expressed himself plainly and uprightly. But, people nowadays insist on seeking marvels and expounding on the lofty and far-reaching. When interpreting texts, they insist on explaining even the obviously shallow commonplace passages in profound phrases. Concerning the outer, they insist on discussing the inner. (ibid.)

Above, we saw that Zhu Xi's approach to inquiry was bound up with the core cultivation efforts of abiding in jing, nurturing the root, and examining self. One's serious learning and reading, especially of the classics, should involve the project of establishing one's great root, in effect, grounding and centring oneself in those patterns, principles, values, and way of life. As Zhu elaborates,

In the conduct of learning, one first must establish the great root. In the beginning, one is quite narrow. In the middle phase of learning, one expands and broadens while at the end one again narrows down. Recently 
learners have liked to pursue the narrow, but without seeking to go on to broaden themselves; how are they then to confirm their narrow understanding? There are also those who seek only to broaden themselves without returning back to the narrow. Their ailment is even worse than that of being too narrow and lacking in breadth. (Zhu 1986, ch. 11)

Zhu regarded the middle stage of learning, the effort of broadening oneself, as the most crucial and painstaking part of learning. This is where one learns about the differences and fine distinctions that make one more discerning and one's responses more appropriate. The narrow "great root" is orientational and pertains to the laying and setting of one's foundation. The process back from breadth to narrowness refers to one's integrating and synthesizing one's wide learning, making it viable for refining one's judgments and actions, making them acute and propitious; this process would be a major step in fulfilling one's existential resolve to be a sensitive, responsible, self-conscious person.

Reading, for $\mathrm{Zhu} \mathrm{Xi}$, is an inherent part of the other cultivation efforts, linked to the broader conduct of inquiry, culminating in investigating things to understand their patterns exhaustively. It is a little-known fact that Zhu was the only prominent Neo-Confucian master to register the central role of reading, and to discuss it extensively. His account of reading with regard to interpreting and understanding classical texts is particularly relevant to discussions on the study of humanities texts today. Importantly, he teaches keeping an open mind about a text, being wary of forcing one's preconceptions and personal views on it, and the important of reading a text over and over again, and immersing and steeping oneself in it. For example, Zhu Xi writes,

In reading, one mustn't foist one's personal views onto the text. Look at it according to the actual meaning of the words; distinguish the meaning of the text clearly on the basis of the words. Review it tirelessly in this way for long days and deep months. (ibid.)

If you read with preconceptions, since they aren't necessarily correct you shouldn't stubbornly stick to them. Just set them aside and read the text over again in order to arrive at a fresh view. (ibid.)

It's like draining muddy water, after which the clear water appears. (ibid.)

For Zhu Xi, besides staying open-minded and free of pre-conceptions, the reader must stay concentrated and focus on the text at hand. 
Review and reread the passages one comprehends. (Zhu 1986, ch. 10)

Just read according to the sequence of the text; each guiding pattern then will appear naturally in context. In this way after a long time, one will experience an overall grasp. (ibid., ch. 11)

One needs this sort of solid mastery of a text for dealing with the problems of interpretation that arise. Moreover, such problems and doubts are inevitable for a serious reader who questions consistency and implications, as well as basic meanings. For example,

The points at which the explanations of various masters differ or agree are worthy of note. Supposing $A$ explains it in one way, just grasp $A$ 's position and examine his account thoroughly; then, suppose $B$ explains it in another way, just grasp $B$ 's position and examine his account thoroughly. Having explored these two masters' positions completely, proceed to investigate the text further and consider the matter exhaustively. Certainly one of the accounts will turn out to be correct. (ibid.) ${ }^{32}$

Encountering doubts and problems are the bread and butter of serious reading, which make it an intriguing exercise, and an utterly unproblematic philosophy text would seem facile and vapid.

Read up to the point at which numerous doubts arise, such that you neglect to sleep and eat. In this way, you can make rapid progress.... It is like deploying troops: you have to score a major kill to be deemed adept at gaining victory. (ibid., ch. 10)

Although one shouldn't concoct groundless explanations, when doubts arise in reading one will form opinions of one's own. At such times, one can't help but form an explanation. Those who haven't formed an explanation simply haven't encountered any doubtful places in their reading. (ibid., ch. 11)

Such valid doubts reflect the seriousness with which one reads. At the same time, the reader's doubts must be well founded and not made up and arbitrary. One who commences reading a text with doubts, in current jargon simply problematizing for the sake of problematizing, is not going to grasp anything or make serious headway in reading. Indeed, feeling and expressing doubt with a true point and purpose depend on a basic initial mastery of the overall text.

32 There is no reason there might not be more than two possible interpretations or readings of a text. 
Otherwise, one won't be equipped to extend doubt meaningfully, not to mention to explain the problem.

Ultimately, such valid exercises of doubt involve bringing one's cultivated knowledge, values, logic, and powers of judgment into play. One's development as a resourceful, passionate thinker proceeds as much through such exercises of doubt as by reading the noble thoughts of the sages.

During their famous symposium at Goose Lake, Zhu Xi wrote the following poem in response to the poems by Lu Xiangshan and his brothers, which celebrated insight learning:

Discuss past learning to increase your subtlety;

Nurture new understandings to increase your depth.

For $\mathrm{Zhu}$, the first line expresses a requirement for carrying out the second. It is best for the intellectual and moral vanguard to nurture their new understandings in the light of the long experience and lasting truths of earlier generations. This is true whether one is basically accepting or rejecting the truths of the past; otherwise, each successive generation will find itself in the position of reinventing the wheel.

Zhu Xi's discussions on reading become more pointed and begin to approximate modern hermeneutics when he considers reading the ancient classics, yet he also finds much to criticize in the predilections of classical commentators of his day. The Book of Changes remains among the most challenging of the classics. As Zhu notes, understanding this text is not simply a matter of understanding the words on the page and the underlying principles; it is a matter of grasping patterns of change and transformation in nature and human life.

The Book of Changes contains detailed information about material facts and covers human affairs thoroughly. All the matters mentioned really occurred. Learners today just review and recite every day beneath their lamp or window without personally having responded or adapted to changes in the world. Suddenly given this book to read, they are ill-prepared to grasp it. (Zhu 1986, ch.11)

The Book of Change describes the patterns/patterning of things and affairs according to transformations of yin and yang. Great and small, seed and chaff, the Book of Changes covers them all. In particular, one can't read it with a biased mind, stressing the inner but neglecting the outer, bored of action and craving ease and tranquillity. (Zhu 2002, ch. 43, letter to Li Kelian) 
Clearly, for Zhu, it is useless to study the Book of Changes in a scholastic way, quietly under a lamp or window. Zhu understands the limits of bookish learning and becoming a well-versed reader without knowing how things actually transpire in the world, and so places equal emphasis on practical experience.

Moreover, Zhu understands that not all canonical texts are equal and present the same sorts of problems to the reader and interpreter. For instance,

Naturally, some books are suitable for anyone to read, such as the $A d-$ vanced Learning, Analects, Mencius and Zhongyong. Indeed, how could one simply not read them? By reading these four books, one grasps the indispensable daoli of daily life, as well as the proper sequence of learning. Afterwards, one can go on to read the Odes, Documents, Rites, and Music. Although I heard others claim they'd read the Book of Changes, I took them to be mistaken because they hadn't observed the proper sequence of learning. The Book of Changes doesn't directly present these daoli and is by no means a common textbook. (Zhu 1986, ch. 67)

Indeed, recognizing that the Book of Changes was originally a divination manual, Zhu first studied the images and the calculations (xiangshu 象數) in the work, treating them as more important than the significance attributed to the text by Cheng Yi. He explains, “...the Book of Changes is especially difficult. Before opening the scripts, one must have made a serious effort to master the images and calculations." (Zhu 2002, ch. 35, letter to Chen Mingzhong)

Since the Book of Odes is a literary text, Zhu Xi's account of his efforts to interpret it is also relevant:

When I interpreted the Odes, I'd just read the original text forty or fifty times and gain a sixty to seventy percent comprehension. Then, I'd see how my impressions jibed with the various commentaries. After I'd gained a general grasp of an ode in this way, I'd reread it thirty or forty more times and become conversant with its main idea, and get it for myself. (Zhu 1986, ch. 80)

Zhu's tended to study individual odes in the Book of Odes in three stages. He'd first recite the ode many times. After attaining a basic mastery of the ode, he would consult the commentaries, which was the second stage. He tended to draw on all of the commentaries, old and new. Having mastered these interpretations, he would reread the ode thirty or forty times more; the third stage. At this point, he usually felt adequately conversant with the daoli of the ode, that he'd "got it for 
himself". Zhu approached the other classics in much the same way he approached the Odes. Consequently, his learning drew upon the traditional readings and was solidly based on original texts. Yet he also ventured to come up with innovative readings of his own.

What's important in becoming well versed in an ode is to immerse oneself completely in reading it a hundred times through. In that way, the exquisite parts will come out and its subtleties and peculiarities will appear. In reading this one ode, you should spare no effort in reading it over and over until you've thoroughly mastered it. Read it like there is no second ode; that would be the best. But, if you just read this first ode and then go on to the second one, you will never succeed in reading it with comprehension. This would be to be lacking in concentration. It is important to slay your "mindset to wander off and pursue other things", so you can just settle down to read. (Zhu 1986, ch. 80)

As a methodical reader, Zhu understands that the Odes has its own inner structure, as does the Book of Changes. In approaching each classic one should first inquire into its inner structure. Consequently, to read the Odes and the Book of Changes simply according to one's initial subjective impressions would not be a valid application of "investigating things to understand pattern exhaustively". Moreover, in reading the Odes Zhu understands that their literary merits transcend the didactic intent of most Confucian interpreters.

In reading the Odes, besides their didactic significance, it's even better to appreciate their literary composition. (ibid.)

An ancient said one may be inspired by reading the Odes (Analects 8/8); what's important is that in reading the Odes one feels inspired at certain points. That is to read the Odes. (ibid.)

The Odes contain moving sentiments. One who reads them without being moved simply is one whose sensibility was slain by the various Confucian commentators. (ibid.)

Completely wash away the old interpretations and the sense of the Odes will come to life. (ibid.)

Zhu Xi's approach to these two classics reveals that his commitment to truth goes well beyond the ideology and didacticism of the Confucian tradition, and that he is keenly interested in the actual patterns, principles, and propensities operative in the world and the deeper sentiments of human life, as expressed through poetry 
and song. Naturally, the books of Confucius, Zisi, and Mencius express valid patterns, principles, and ideals that $\mathrm{Zhu} \mathrm{Xi}$ embraces and identifies as his own, yet at the same time he examines and comments on these texts with the same keen critical eye. We thus see Zhu registering several levels and valences of truth corresponding to the course of nature and human life, the deeper sentiments of humanity, and Way and teachings of Confucius and the sage kings and formative Confucian masters.

Concerning Zhu Xi's quest for truth in these ways, Peng Guosheng usefully compares his approach to reading and interpreting the Confucian classics with HansGeorg Gadamer's philosophical hermeneutics. While Zhu Xi engages in what may be termed Gadamerian baseline textual interpretation to elicit the original meaning(s) of the extant text, and second order textual reconstruction to clarify and elaborate the guiding principles at work it, particularly with respect to the Four Books, and with an eye to praxis, Zhu exhibits a sort of exuberance in his readings and commentaries that is not evident in drier Gadamerian approaches (Peng 2015, 326). Peng accounts for Zhu's exuberance in his reading and interpreting as due to his not just participating in, but devotedly cultivating himself, in "sacred" Confucian traditions.

In my view, Zhu Xi's exuberance about not just learning and reading but inquiry in general traces back to his inveterate hunger to probe to the marrow, and understand deeply and practically the world and human existence. His existential resolve to realize himself as a sensitive, responsible, self-conscious person is not just to fulfil the Confucian ideal, but more broadly to be conversant with the flux of reality in nature as well as himself. Certainly, he would advise today's advanced humanities researchers and writers not only to delve whole-heartedly into their focal concerns, but also have a healthy interest in a broad array of matters and phenomena.

\section{Zhu Xi on Extracurricular Learning}

Zhu $\mathrm{Xi}$ was rather unique in the Confucian tradition for seeking a firm grasp of the patterns of change and transformation that constitute the world and human life. ${ }^{33}$ Most of his Neo-Confucian brethren devoted themselves more narrowly to what they considered orthodox learning, and often sought to purge "extracurricular

33 It might be contested that this impulse underlay the production and use of the Book of Changes, and that Shao Yong anticipated Zhu Xi with the notion of observation. I would reply that among Confucian scholars $\mathrm{Zhu} \mathrm{Xi}$ did the most to think about and develop a method of investigating things to extend knowledge. He developed this notion in greater depth and applied it more broadly than had Shao Yong or any other Confucian in traditional China. 
materials". Some regarded even literary and historical inquiries as borderline extracurricular, creating for themselves the appearance of empty moralizers and lifeless pedants. By contrast, $\mathrm{Zhu} \mathrm{Xi}$ sought to understand the dynamics and depths of life and conducted his own learning in a broad and encompassing way. To his Neo-Confucian peers, he would ask, "How can one claim to grasp and carry out the Way if one doesn't have a handle on the ways of the world and society in which one lives, if one doesn't register the pulse of everyday life?" As emphasized by Qian $\mathrm{Mu}$, the scope of Zhu's "investigating things to understand pattern exhaustively" was potentially all-embracing, and so his pursuit of learning extended into what other Confucians would regard as borderline areas and beyond. Two extracurricular realms of particular interest to $\mathrm{Zhu} \mathrm{Xi}$ were roaming freely in the arts and investigating natural knowledge (Qian 1991, 215). ${ }^{34}$

Confucius advised his students to roam freely in the arts in their free time. $\mathrm{Zhu} \mathrm{Xi}$ saw value in such roaming, in that it encourages one to notice the little things, the details, the finer things at hand in daily life, and that it allows one to continue cultivating oneself whether in action or repose. In this way, every moment becomes a precious occasion to be unlocked and appreciated. Indeed, Zhu considered that learners who thus stay in the moment during downtime as well as up-time would tend to have a firmer sense of priorities, and be prone to nurture root and branch, inner and outer together.

For his part, Zhu Xi took joy in painting and drawing, and did some self-portraits. $\mathrm{He}$ also enjoyed the lute and was versed in harmony and melodies. When a master of the lute, Cai Yuanding (Jitong, 1135-1198), came to study with him, Zhu received him as an old friend and later discussed the instrument in a letter to the master that linked the principles of the lute with the appropriateness and patterns of the myriad things:

Generally speaking, as to the myriad affairs in the world, their appropriateness and patterns are inexhaustibly subtle; it isn't easy to determine them thoroughly in a word. One must peer through them as through a crystal screen such that they do not obstruct one another; that is a confirmation of investigating things. (Zhu 2002, ch. 44, letter to Cai Jitong)

Zhu also studied the major works on health, medicine, and the principles of nourishing life, and discussed them knowledgeably. He even investigated the art of quiet-sitting to nourish life, and discussed this with Cai Yuanting in connection with the Daoist text Can-tong-qi 參通契 (The Three Ways Unified and

34 The following examples were drawn from Qian 1991, ch. 30. 
Harmonized). When Cai was about to go into exile, Zhu discussed the Cantong-qi with gusto when seeing him off. Incredibly, Zhu later wrote a commentary on this text under the nom d'plume Kongtong daoshi Zou Xin 空同道 士鄒訢 (Daoist master of vacuity and identity Zou Xin). Some later scholars ridiculed him for writing this commentary; however, they hadn't grasped that Zhu's version of Neo-Confucianism was all embracing, and thus included these other dimensions. ${ }^{35}$

As noted above, Zhu's method of investigating things was applicable in principle to everything from the cosmos and heavens above, to humanity and the myriad creatures below. Moreover, Zhu's entire effort manifested and authenticated his resolve to attain and extend knowledge by "investigating things to understand patterns exhaustively". It must be noted that while Zhu's teaching of "investigating things" was more about culture and ethics than scientific matters, he did make some salient scientific or proto-scientific observations at a time when few Chinese intellectuals concerned themselves with such things, and officialdom did not hold technologists or engineers in very high regard (Kim 2000). Zhu Xi made numerous observations of natural phenomena couched in (and to a certain extent rationalized) in his $l i-q i$ conceptual framework. He always sought the underlying patterns and qi permutations of the natural phenomena he observed-as well as of the human conduct and texts he investigated. The following are several examples of Zhu Xi's observations of and reflections on natural phenomena.

At several times, Zhu Xi observed fossil shells on mountaintops, and with some amazement inferred a notion of geological evolution in light of received principles of transformation. He writes, for example,

I often see the snail and clam shells atop high mountains, or embedded inside stones: these stones are made of the soil of an earlier time. But, snails and clams live in the water. Thus, the low transforms into the high, the soft transforms into the hard. These matters, if one thinks deeply about them, involve facts that can be confirmed. (Zhu 1986, ch. 94)

Now there are often various types of oyster shells embedded in stones atop high mountains. Oysters must certainly live in the mud but, there they are, in stone. Heaven and earth are changing and rotating; how can anything remain constant? At the time when the mountains, rivers and the great Earth were first produced, their settings must have been quite soft. (Zhu 1985, ch. 1)

35 This text could be regarded as an extension or application of Zhou Dunyi's Explanation of the Diagram of the Supreme Polarity, the cornerstone of Zhu Xi's system of thought. 
Moreover, while Zhu held that the earth was stationary vis-à-vis the rotating heavens above, later when he considered that the earth lies nested below or within the heavens, he raised the question that while

Heaven rotates on the outside, isn't the earth revolving along with it? Sitting here now, we don't feel that the earth is moving, but how do we know that while heaven rotates on the outside the earth isn't revolving along with it? (Zhu 1985, ch. 86) ${ }^{36}$

$\mathrm{Zhu} \mathrm{Xi}$ also offered a probing reflection on the formation of the cosmos. Reminiscent of Spinoza's notion of immanent reason and Wittgenstein's logical space, he regarded patterns/patterning as penetrating everything and not conditioned or limited by extension, dimension, or direction. By the same token, he understood that almanac makers only catch certain discernible annual cycles and seasonal patterns in the world; they cannot register anything deeper or get into the hows or whys these phenomena.

Someone said, "Shao Yong spoke of that which 'lies beyond the six directions.' I fear there is nothing beyond them." The Master replied, "Assuredly, pattern is free of inner and outer. The pattern of the six directions certainly has inner and outer. When almanac makers calculate the $q i$, they just calculate the revolutions of the sun, moon, and stars. Beyond this, they cannot calculate. And, how could these matters be free of inner and outer?” (Zhu 1986, ch.1)

As to comprehending heaven, the cosmos, and its revolutions more generally, Zhu speaks exuberantly of expanding one's mind and feelings, one's consciousness; by extending from all that one feels, sees, knows, and can imagine, one can begin to get a sense of its immensity. This appears to be an application of Zhu Xi's method of "investigating things to attain knowledge" to nature writ large:

Heaven is just a vast entity; one must enlarge one's mind and feelings to begin to gaze upon it. As to the revolution of heaven, in one day it definitely revolves in one cycle. But, there are also major revolution cycles; one cannot approach this matter from just one perspective. (Zhu 1985, ch. 1)

It is fascinating to consider the sorts of existential reflection that would accompany such reflective observations of nature itself.

Interestingly, besides making such discerning scientific remarks, Zhu Xi sometimes also came up with what might be deemed a scientific or proto-scientific

36 This is the sort of question that Copernicus, Kepler, and Columbus were asking themselves. 
model or thought experiment to facilitate understanding of natural phenomena. In one such case, Zhu uses a steaming rice pot as a model for understanding precipitation:

When $q i$ vaporizes and produces rain, it is just like when the rice pot is covered: the qi pressurizes, condenses, and produces droplets. When $q i$ vaporizes and produces fog, it is just like when the rice pot isn't covered: the $q i$ disperses and is not recovered. (Zhu 1985, ch. 111) ${ }^{37}$

Zhu $\mathrm{Xi}$ was at once rational and empirical in spirit. He observed events carefully with a keen eye and yet sought underlying patterns and offered reasoned speculations on the workings of natural phenomena. He found such inquiries into natural truths invigorating, almost empowering, touching reality in ways that cultural, textual truths never could. Zhu was deeply interested in the patterns constituting, connecting, and guiding physical phenomena; and he investigated natural phenomena in the spirit of roaming freely in the arts, that is, he didn't neglect to observe even the most trifling matters. And, as in his conduct of textual studies and formation of cultivation approaches, he strove to confirm his ideas and hypotheses against the evidence or the touchstone of effectiveness, often in dynamic terms, more in the sense of asking whether that was "how something worked" in situ, rather than whether "it was simply true or false". In any case, he wouldn't accept claims or ideas without some indication of their truth, their practical veracity. For example:

A while back, there was a monk who claimed, "In the growth of bamboo sprouts one can observe the 'night vapor'. So, I stuck a pole into the ground to record the growth of a bamboo sprout. From morning until night it grew less than one inch. When I observed it at dawn the next day, it had already grown by several inches." Afterwards, I tested the story at the Jade Mountain Monastery, and found that the bamboo sprouts grew the same amount by day or night. Their actual growth differed entirely from that claim of the monk. (Zhu 1986, 138)

Qian Mu notes that this story presents an interesting contrast to Wang Shouren's anecdote about investigating the bamboo in front of his hall. While the young Wang just sat there and stared blankly at bamboo sprouts expecting their patterning to be manifested before his eyes, and gained no knowledge from the

37 It is a shame that nobody realized that the pressurized steam in a vessel could produce power. Laozi planted the seed for this discovery in Laozi, ch. 11. But the suggestion was never noticed. See Ames and Hall $(2003,91 \mathrm{f})$. 
exercise, Zhu's teaching and practice of "investigating things" involved observing with a clear question in mind, to be tested and confirmed. Thus, after hearing the monk's claim about the growth of the plants, Zhu proceeded to measure the actual growth of the bamboo sprouts by day and night when he had some free time (Qian 1991, 219).

Above, we observed that $\mathrm{Zhu} \mathrm{Xi}$ would have questioned the narrowness and over-professionalization of current humanities research and writing at the college level. In this age of accelerated advanced degree programs, scholars are no longer limited just to the boundaries of their disciplines, but now to their chosen areas and fields within their disciplines. ${ }^{38}$ This trend not only erodes the scholars' awareness of the intellectual-historical context of their chosen academic niches, but also alienates them from the constellations of other disciplines surrounding their own. $\mathrm{Zhu} \mathrm{Xi}$ realized that his own focal concerns, such as the Confucian Way, self-cultivation, and so on, could only be understood, attested, and made more meaningful within larger contexts of knowledge and awareness. His central preoccupations could only come alive when related to a working sense of the world, history, his tradition, other traditions, human nature, and the like. Consequently, his example demonstrates that humanities students and researchers should acquaint themselves broadly within their own field, as well as with smatterings of other fields, in order to add depth and reality to their thought and research. In my case, my earlier efforts to study some science and the philosophy of science were repaid not only in a firmer grasp of recent developments in this area, but also in the writing of a crucial book review (Thompson 2002) and academia presentation (Thompson 2016). These studies also facilitated my recent work in agricultural and sustainability ethics, which has reinvigorated my academic and professional life. ${ }^{39}$

Calls to expand the purview of one's interests and learning-so as to include not only attending to and grasping the flow of events going on, whether at hand or in the press, but also making oneself aware of and conversant in ever wider swaths of one's own discipline, as well as trends of others-perhaps sound like a siren's call, an impossible dream, in this age of information overload. At present, our focal studies and research efforts are already vastly overwhelmed by the wealth of information at our grasp with the aid of digitization, computers, and the internet. We used to despair at reams of information, now new information pours in by the gigabyte and megabyte! How can we be expected to cast our vision beyond this focal amplitude, this infinite depth, which we can barely begin to get a grip on? In

38 I once heard an American Chinese historian say that he was only knowledgeable about the last fifty years of the Tang dynasty and not to ask him about the early Tang or any other period of Chinese history. Hopefully, he was exaggerating.

See also Thompson 2012a, 2012b, and 2013. 
this time and age, such calls, as implied in Zhu Xi's teaching and practice, seem delusional if not downright sadistic. However, I maintain that this call is crucial if contemporary humanities researchers and writers are to restore a sense of not only their intellectual balance and equilibrium, but also of their academic commitments and life direction. It is crucial, indeed, to keeping one's academic work and career relevant to life as well as in harness with one's primary resolve to be a sensitive, responsible, self-conscious human being.

Now to the question, how is the contemporary humanities researcher to do this? That is, how is she to keep abreast developments in her own area, not to mention her field at large, while keeping aware the events going on in other fields of knowledge? After all, there are only 24 hours in a day, and seven days in a week! Well, to this end, the internet may be of service. One may subscribe to several news and academic sites to receive periodic newsletters. One may choose news sites that reflect one's outlook and politics, although it would be healthier to also receive postings of contrary views. Among academic sites, one may choose some that directly reflect one's interests, although again it would also be good to receive newsletters with a more general interest in the field, as well as science reports, such as from the New Scientist or Science Nerwsletter. One might visit the new books shelf and the current periodicals room at a university library, say, twice per month, to browse everything. It would also be intellectually expansive to read books from other fields at least once or twice a year, not just for expanding one's intellectual breadth, but for challenging oneself to explore outside one's intellectual comfort zone.

\section{Conclusion}

Zhu Xi's views and teachings on inquiry, learning, and reading, as understood in the context of his approach to self-cultivation, are highly relevant for rethinking and addressing the state of advanced education, study, research, reflection, and writing in the contemporary academy, especially in the humanities. While the tools of digitization, computers, and the internet grant us access to unimaginable riches of information, and empower us to explore and crunch that data, they and their applications in MOOCs, distance learning, and video classrooms are ultimately dehumanizing in various ways, and detract from the animating spirit of humanities studies. Consequently, we in this day and age are rapidly losing touch with some of the core elements of humanities education and learning. These elements are closely connected with the human touch, the personal touch, and are directly involved with the reasons why one enters the humanities in the first 
place. They have to do with the human spirit, with questions of the meaning and purpose of human life, with the reasons why we all find the courage and conviction to get up in the morning to face yet another day-or not. So much of the true and significant humanities work depends on personal immersion in the focal materials, struggling with them, trying to read the author behind the writings, attempting to make personal sense of his or her productions, efforts that easily become vapid on computer monitors when one is easily distracted by other things online. So much of humanities training and interning involves teachers and students, or just the latter, intensively reading and discussing core texts together, trying to make general sense of these texts together while seeking personal meaning for oneself or one's set. Such activities and quests animated several advanced courses I took in philosophy and literature as a university student, for example on Plato, Melville, Thoreau, the Romantics, Kierkegaard, Nietzsche, Wittgenstein, and others, and as a graduate student, such as on Laozi, Zhuangzi, Seng Zhao, the Neo-Confucians, and so forth. ${ }^{40}$ These sorts of activities can be mimicked in online chat rooms, but those dialogues never carry the same feeling or punch as face-to-face conversations.

This sort of humanities spirit and practice underlay Zhu Xi's experience, commitment, practice and teaching, which makes his ideas continue to be relevant and suggestive even today, when this personal and face-to-face sort of learning and study are being supplanted by digital and online tools and apps. Fundamentally, $\mathrm{Zhu} \mathrm{Xi}$ reminds us that the value of the humanities, and of advanced work in this field in particular, lies precisely in one's establishing the existential resolve to see the project through, not merely as an intellectual task to be completed, but even more as part of the existential humanizing project of cultivating oneself into a more sensitive, reflective, responsible, self-conscious human being.

In closing, what Kleinbaum wrote of poetry could certainly be said broadly of the humanities, and Zhu Xi would concur:

...We read and write poetry because we are members of the human race. And the human race is filled with passion. Medicine, law, business, engineering... are noble pursuits and necessary to sustain life. But poetry, beauty, romance, love.... These are what we stay alive for. (Kleinbaum 1989) ${ }^{41}$

40 These readings and activities made these courses absolutely crucial in my personal development as a sensitive, responsible human being, as well as a humanities scholar.

41 A theory obsessed literature colleague called The Dead Poets Society a nice, sentimental story. I replied that this story gets at why we as human beings produce, enjoy and study poetry, and literature generally, in the first place. Theory often loses sight of this, and becomes irrelevant to appreciating and responding to what is humanly important and interesting in literature. 


\section{References}

Ames, Roger, and Henry Rosemont. 1998. The Analects of Confucius: A Philosophical Translation. New York: Ballantine Books.

Ames, Roger, and David Hall. 2003. Dao De Jing: A Philosophical Translation: "Making This Life Significant". New York: Ballantine Books.

Austin, James. 2003. Chase, Chance, and Creativity: The Lucky Art of Novelty. Cambridge, MA: MIT Press.

Chan, Wing-tsit, comp. and trans. 1963. A Source Book in Chinese Philosophy. Princeton: Princeton University Press.

Flynn, Thomas R. 2014. Sartre: A Philosophical Biography. Cambridge: Cambridge University Press.

Guthrie. W.K.C., trans. 1956. Plato: Protagoras and Meno. London: Penguine Books.

Hall, David, and Roger Ames. 1987. Thinking Through Confucius. Albany: SUNY Press.

Hawkins, Jeff. 2004. On Intelligence. New York: Holt, and Owl Book.

Kim, Yung-sik. 2000. The Natural Philosophy of Chu Hsi (1130-1200). Philadelphia: American Philosophical Society.

Kleinbaum, N.H. 1989. Deat Poets Society. New York: Hyperion Books.

Lau, D.C., trans. 1970. Mencius. London: Penguin Books.

Nussbaum, Martha. 1998. Cultivating Humanity: A Classical Defense of Reform in Liberal Education. Cambridge, MA: Harvard University Press.

Polanyi, Michael. (1966) 2009. The Tacit Dimension. Chicago: The University of Chicago Press.

Qian, Mu. 1991. Zhuzi xin-xue'an. Taipei: Dongda.

Ryle, Gilbert. 1949. The Concept of Mind. Chicago: The University of Chicago Press.

Thompson, Kirill. 2002. "Review of The Natural Philosophy of Chu Hsi 1130-1200, by Yung Sik Kim.” (Philadelphia: American Philosophical Society, 2000). In China Review International 9 (1), Spring: 165-80.

—. 2012a. "Traditional Knowledge - China." The Berkshire Encyclopedia of Sustainability: China, India, and East and Southeast Asia: Assessing Sustainability, vol 7. Great Barrington: Berkshire.

—. 2012b. "Agricultural Ethics in East Asian Perspective: Some Issues." Paper presented at an "International Conference on Agricultural Ethics in East Asian Perspective," held in Taipei, Taiwan on March 1, 2012.

—. 2013. "Agrarianism and the Ethics of Eating." In Encyclopedia of Food and Agriculture Ethics, edited by Paul B. Thompson and David M. Kaplan, 29-38. Dordrecht: Springer. 
—. 2016. "Daoism, Zen, Time Awareness, and the Reality of Time." Presented at the "UBIAS Intercontinental Academia on Time, Nagoya Workshop," March 6-18, 2016.

Wade, David. 2004. Li: Dynamic Form in Nature. New York: Walker and Co.

Watson, Burton. 1968. The Complete Works of Chuang Tzu. New York: Columbia University Press.

Zhu Xi. 1977. Zhuzi quanshu. Edited by Li Guandi Rpt. Taipei: Guangxue.

- 1986. Zhuzi yulei. Beijing: Zhonghua shuju.

-. Rpt. 2002. Zhu wengong wenji (1532). Collected in Zhu, J., edited by Z. Yan, and Y. Lu

—. Rpt. 2002. Zhuzi quanshu (1714), vols. 20-25. Shanghai: Shanghai guji chubanshe. 